\title{
Analisis Strategi Positioning Merek Berdasarkan Preferensi, Persepsi, dan Kepuasan Konsumen Produk Pertamina Lubricants
}

\author{
Fakhri Anggara, Berto Mulia Wibawa, dan Aang Kunaifi \\ Jurusan Manajemen Bisnis, Fakultas Teknologi Industri, Institut Teknologi Sepuluh Nopember (ITS) \\ Jl. Arief Rahman Hakim, Surabaya 60111 Indonesia \\ e-mail: bertomuliawibawa@gmail.com
}

\begin{abstract}
Abstrak-Potensi industri pelumas sebagai industri strategis kian bertumbuh dari tahun ke tahun. Hal ini disebabkan oleh meningkatnya penggunaan pelumas pada pasar otomotif dan juga perindustrian. Pertumbuhan potensi ini menarik bagi para produsen lokal maupun internasional. Penelitian ini bertujuan untuk menganalisis sejauh mana atribut pelumas dapat mempengaruhi evaluasi konsumen terhadap positioning merek dan kompetisi terhadap merek lain, menganalisis faktor-faktor yang mempengaruhi kepuasan konsumen terhadap produk Pertamina Lubricants juga merumuskan alternatif strategi positioning berdasarkan persepsi dan kepuasan pelanggan. Penelitian ini menggunakan desain riset konklusif dan merupakan riset deskriptif. Teknik sampling yang digunakan adalah convenience sampling. Penelitian ini menggunakan metode survei. Sampel pada penelitian ini adalah para pelanggan Pertamina Lubricants di daerah Jawa timur sejumlah 240 responden. Penelitian ini menggunakan perceptual map yang dikembangkan dengan menggunakan analisis diskriminan berganda, untuk menggambarkan posisi relatif setiap merek dan menggambarkan atribut merek tersebut. Hasil dari penelitian ini menunjukkan bahwa secara keseluruhan produk Pertamina Lubricants dicirikan dengan 3 atribut yaitu kemudahan diperoleh, harga dan kepopuleran merek. Selanjutnya dengan menggunakan analisis regresi berganda diketahui keenam atribut memiliki pengaruh positif signifikan terhadap manfaat yang dirasakan konsumen, atribut yang memiliki pengaruh paling besar adalah harga dan kepopuleran merek. Hasil dari analisis regresi sederhana didapati bahwa manfaat yang dirasakan berpengaruh positif signifikan terhadap kepuasan pelanggan. Penelitian ini memberikan metode yang unik untuk memahami struktur pasar dan menentukan tujuan dari merek dan juga posisi terbaik yang kompetitif untuk Pertamina Lubricants.
\end{abstract}

Kata Kunci-Analisis Diskriminan Berganda, Analisis Regresi, Pelumas, Peta Persepsi, Positioning

\section{PENDAHULUAN}

$\mathrm{P}$ OTENSI industri pelumas terus bertumbuh bersamaan dengan meningkatnya jumlah kendaraan bermotor dari tahun ke tahun. Pertumbuhan industri pelumas juga didorong oleh perkembangan sektor industri yang meliputi produksi dan konstruksi [6]. Pelumas bagi kendaraan dan juga mesin perindustrian merupakan hal yang sangat penting. Mesin yang digunakan pada kendaraan bermotor ataupun perindustrian tentunya membutuhkan pelumas untuk perlindungan. Pertambahan jumlah kendaraan dan juga perkembangan sektor perindustrian akan menyebabkan pertumbuhan industri pelumas.

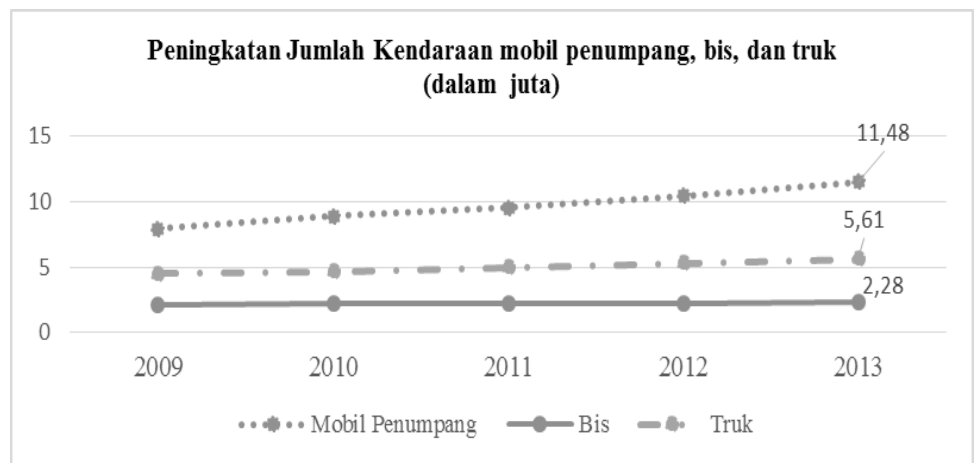

Gambar 1 Peningkatan jumlah kendaraan tahun 2009-2013

Di Indonesia terdapat banyak perusahaan pelumas yang bermain di pasar industri pelumas. Beberapa di antaranya adalah perusahaan multinasional, seperti Shell, Exxon Mobil, BP, Caltex dan Total FinalElf. Banyak sekali merek-merek pelumas yang beredar di Indonesia. Berlakunya MEA (Masyarakat Ekonomi Asean) pada akhir Desember 2015 telah memicu persaingan antara pemain utama produsen minyak nasional dan juga internasional. Para produsen minyak nasional maupun internasional berlomba untuk meningkatkan cengkraman di pasar pelumas.

Pertamina Lubricants sebagai satu-satunya pemain lokal, harus bisa bersaing dengan para perusahaan multinational yang bermain di industri yang sams. Brand positioning atau biasa kita sebut positioning merek sangatlah penting dan perlu diperhatikan. Karena dengan menggunakan positioning dapat menambah awareness konsumen pada sebuah produk. Positioning merek mengacu kepada ingatan konsumen terhadap sebuah produk, karena setiap merek memiliki ciri-ciri atau atribut yang speisifik menurut [1]. Positioning merek bergantung pada persepsi pelanggan mengenai atribut dari sebuah produk, dimana dengan adanya atribut-atribut khusus atau ciri-ciri dari sebuah produk dapat memungkinkan konsumen untuk membedakan dan membuat perbandingan antara produk yang bersaing.

Hal yang bisa diambil dari pemaparan diatas adalah bagaimanakah produk pelumas Pertamina bisa meningkatkan daya saing mereka terhadap para pesaingnya. Salah satu cara meningkatkan daya saing produk pelumas Pertamina adalah 
dengan menentukan strategi positioning yang tepat. Positioning merek yang tepat dapat meningkatkan awareness para konsumen terhadap produk-produk Pertamina Lubricants.

Persaingan yang semakin ketat pada industri pelumas saat ini membuat Pertamina Lubricants harus bisa menentukan strategi positioning yang tepat, maka perumusan masalah pada penelitian ini adalah bagaimana pengaruh preferensi, persepsi, dan kepuasan konsumen pada produk Pertamina Lubricants terhadap strategi positioning merek agar bisa memenangkan persaingan pada pasar pelumas.

\section{METODOLOGI PENELITIAN}

\section{A. Desain Penelitian}

Pada penelitian kali ini menggunakan desain konklusif. Konklusif memiliki karakteristik untuk menguji hipotesis dan menguji hubungan informasi yang dibutuhkan [8]. Sesuai dengan tujuan dari penelitian ini yaitu menentukan peta strategi merek dari Pertamina Lubricants dan juga menganalisis bagaimanakah persepsi dan preferensi konsumen pada produk Pertamina Lubricants dan hal apa saja yang mempengaruhi kepuasan konsumen pada produk ini. Lebih tepatnya penelitian ini merupakan descriptive research yang menggunakan rancangan penelitian cross sectional.

\section{B. Teknik Pengumpulan Data}

Penelitian ini dilakukan pada tiga kota di Jawa timur yaitu kota Surabaya, Gresik, dan Sidoardjo. Waktu penelitian berlangsung dari bulan Februari sampai dengan Juni 2016. Subjek dari penelitian ini adalah para pengguna produk Pertamina Lubricants yang berada di daerah Jawa Timur baik sebagai pengguna akhir maupun pengguna di bidang industri. Sedangkan yang menjadi objek pada penelitian ini adalah 8 kategori produk Pertamina Lubricants. Data yang digunakan pada penelitian ini merupakan data primer yang didapatkan melalui metode survei. Metode survei dilakukan dengan cara menyebarkan kuesioner kepada responden. Kuesioner yang disebar terdiri dari empat bagian yaitu bagian screening, bagian demografi responden, bagian analisis regresi, dan bagian analisis diskriminan. Pada penelitian kali ini menggunakan salah satu jenis dari skala interval yaitu skala Likert. Menurut Sugiyono [12] skala Likert adalah skala yang biasa digunakan dalam mengukur sikap, pendapat dan persepsi seseorang terhadap sebuah fenomena. Skala Likert yang digunakan adalah skala Likert 5 untuk mengukur respon terhadap perceived value dan juga kepuasan pelanggan. Pada penelitian ini menggunakan teknik non-probability sampling yaitu convenience sampling. Karena penelitian yang menggunakan metode statistik membutuhkan jumlah sampe minimum 30 [11], dan terdapat 8 kategori produk yang diamati sehingga total responden yang dibutuhkan pada penelitian ini sebanyak 240 responden.

\section{Teknik Pengolahan dan Analisis Data}

Pada penelitian ini menggunakan beberapa metode dalam melakukan pengolahan dan analisis data. Langkah pertama dalam melakukan pengolahan data adalah analisis deskriptif. Analisis deskriptif yang dilakukan meliputi Perhitungan rata- rata, distribusi frekuensi, dan distribusi persentase adalah bentuk yang paling umum dari peringkasan data [13].

Langkah selanjutnya adalah melakukan uji outlier dan juga missing data untuk memastikan bahwa tidak ada data yang hilang dan juga data yang terlihat sangat berbeda jauh dari observasi lainnya [3]. Selanjutnya adalah melakukan uji validitas dan reliabilitas dengan menggunakan metode confirmatory factor analysis dan juga melihat nilai Cronbach's alpha. Uji asumsi klasik juga dilakukan sebelum masuk kedalam pengolahan data lebih lanjut. Adapun uji asumsi klasik yang dilakukan adalah uji normalitas, uji linearitas, uji multikolinearitas dan uji homoskedastisitas.

Setelah dilakukan uji asumsi klasik maka bisa dilanjutkan dengan langkah berikutnya yaitu tahap analisis data. Tahap analisis pertama yang dilakukan adalah menggunakan analisis diskriminan berganda untuk melakukan analisis positioning pada kategori produk Pertamina Lubricants. Adapun persamaan matematika dari analisis diskriminan berganda bsia dituliskan sebagai berikut:

$D=b_{0}+b_{1} x_{1}+b_{2} x_{2}+b_{3} x_{3}+\cdots+b_{k} x_{k}$

Dalam mengevaluasi positioning merek, terdapat beberapa metode yang dapat digunakan yaitu, MDS (multi-dimensional scaling), discriminant analysis, dan juga multi-atribute decision model [7]. Ada beberapa alasan mengapa analisis diskriminan adalah metode yang digunakan, Salah satu alasannya adalah apabila informasi mengenai atribut diketahui secara mendalam analisis faktor dan juga analisis diskriminan adalah metode yang lebih akurat dibandingkan dengan MDS [5]. Dengan menggunakan analisis diskriminan berganda selanjutnya akan digambarkan persaingan yang terjadi antara Pertamina Lubricants dengan merek-merek pesaing menggunakan perceptual map.

Metode analisis terakhir yang dilakukan adalah analisis regresi. Terdapat dua model regresi pada penelitian ini yaitu regresi linear berganda dan juga regresi linear sederhana. Regresi linear berganda digunakan untuk mengukur pengaruh dari variabel independen yang merupakan atribut dari pelumas yaitu performa $\left(\mathrm{X}_{1}\right)$, usia pakai $\left(\mathrm{X}_{2}\right)$, kemudahan diperoleh $\left(X_{3}\right)$, harga $\left(X_{4}\right)$, kemasan $\left(X_{5}\right)$ dan kepopuleran merek $\left(X_{6}\right)$ terhadap variabel dependen yaitu manfaat yang dirasakan $\left(\mathrm{Y}_{1}\right)$ dengan model sebagai berikut:

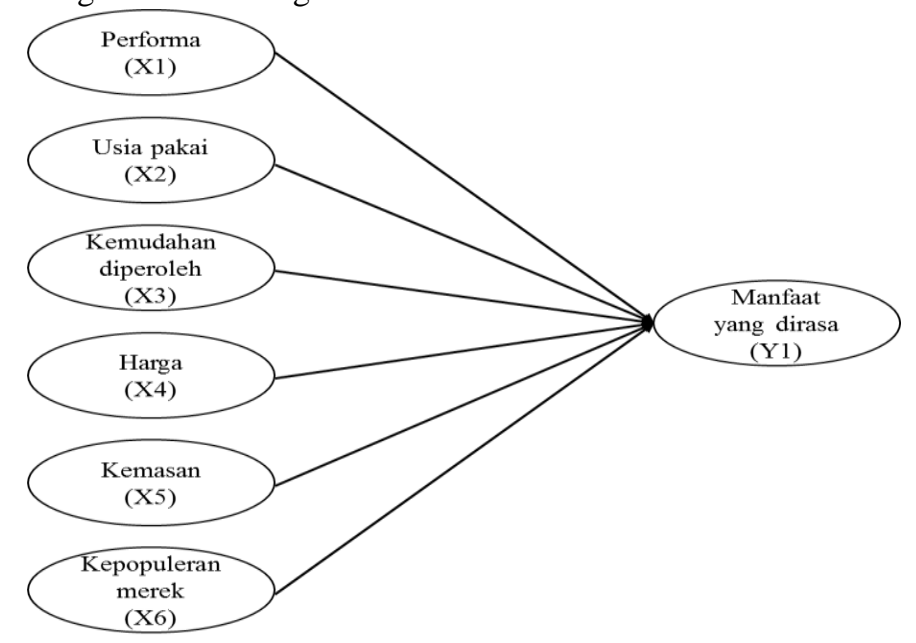

Gambar 2 Model regresi linear berganda 
Untuk analisis linear sederhana pada penelitian ini digunakan untuk mengukur pengaruh dari variabel independen manfaat yang dirasakan $\left(\mathrm{Y}_{1}\right)$ terhadap variabel dependen kepuasan pelanggan $\left(\mathrm{Y}_{2}\right)$ dengan model regresi sebagai berikut:

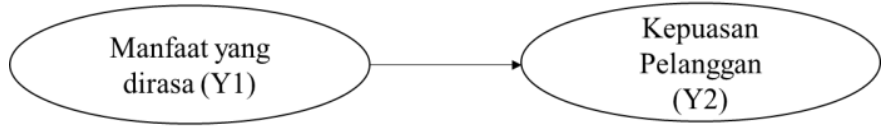

Gambar 3 Model regresi linear sederhana

Berdasarkan model regresi berganda dan juga model regresi sederhana, terdapat 7 hipotesis pada penelitian ini. Mengacu pada penelitian sebelumnya yang dilakukan oleh [10] dan dihubungkan dengan pendapat [14] mengenai manfaat yang dirasakan dan juga kepuasan konsumen, maka hipotesis yang dikembangkan dalam penelitian ini adalah sebagai berikut:

- $\mathrm{H}_{1}=$ Performa oli berpengaruh positif signifikan terhadap mafaat yang dirasa.

- $\quad \mathrm{H}_{2}=$ Umur pakai oli berpengaruh positif signifikan terhadap manfaat yang dirasa.

- $\mathrm{H}_{3}=$ Kemudahan diperoleh berpengaruh positif signifikan terhadap manfaat yang dirasa.

- $\mathrm{H}_{4}=$ Harga berpengaruh positif signifikan terhadap manfaat yang dirasa.

- $\quad \mathrm{H}_{5}=$ Kemasan berpengaruh positif signifikan terhadap manfaat yang dirasa.

- $\mathrm{H}_{6}=$ Kepopuleran merek berpengaruh positif signifikan terhadap manfaat yang dirasa.

- $\quad \mathrm{H}_{7}=$ Manfaat yang dirasa berpengaruh positif signifikan terhadap kepuasan pelanggan.

\section{ANALISIS DAN DISKUSI}

\section{A. Analisis deskriptif}

Berdasarkan hasil penyebaran kuesioner yang dilakukan terdapat 240 data responden yang akan diuji pada penelitian kali ini. Sebanyak $88 \%$ responden pada penelitian ini adalah lakilaki dan sisanya $12 \%$ merupakan perempuan. Sedangkan untuk pendidikan responden didominasi oleh lulusan SMA/ sederajat yaitu sebesar $73 \%$. Usia responden pada penelitian ini sangat beragam, namun didominasi oleh rentan 36-45 tahun sebesar $37,1 \%$. Responden yang bekerja sebagai pegawai swasta merupakan responden dengan presentase terbesar sebesar $69,6 \%$.

\section{B. Uji Validitas dan Reliabilitas}

Hasil dari uji validitas yang dilakukan menggunakan confirmatory factor analysis dengan melihat nilai loading factor pada indikator-indikator setiap variabel. Acuan utama yang digunakan untuk melihat apakah indikator-indikator tersebut sudah mendukung penelitian adalah apabila nilai standardized regression weight $>0,50$ [4]. Seluruh indikator pembentuk variabel memiliki nilai loading factor di atas 0,5 sehingga bisa dinyatakan bahwa seluruh indikator pembentuk variabel telah valid. Untuk menguji keandalan atau reliabilitas dari kuesioner akan dilakukan dengan melihat nilai cronbach's alpha dengan cut-off value > 0,6 [4]. Seluruh variabel memiliki nilai cronbach's alpha diatas 0,6 sehingga bisa dikatakan realiabel.

\section{Uji Asumsi Klasik}

- Uji Normalitas

Pada penelitian ini dilakukan uji normalitas dengan menggunakan 2 metode yaitu menggunakan visualisasi dengan menampilkan normal probability plot dan yang kedua menggunakan uji Kolmogorov smirnov. Berdasarkan hasil uji normalitas yang telah dilakukan, pada normal probability plot menunjukkan titik-titik terkumpul dan mengikuti garis lurus sehingga data bisa disimpulkan mengikuti distribusi normal [3]. Hasil dari normal probability plot juga diperkuat oleh hasil uji Kolmogorov smirnov. Nilai dari signifikansi Kolmogorov smirnov pada model regresi dan juga diskriminan menunjukkan lebih besar dari 0,05 sehingga dapat disimpulkan data terdistribusi secara normal.

\section{- Uji Linearitas}

Uji linearitas pada penelitian ini sendiri menggunakan matriks scatter plot yang melibatkan seluruh variabel penelitian. Variabel yang terlibat adalah performa, usia pakai, kemudahan diperoleh, harga, kemasan, kepopuleran merek, manfaat dan kepuasan. Hasil dari matriks scatter plot menunjukkan bahwa hubungan antar variabel secara keseluruhan memiliki sifat yang linier.

- Uji Multikolinearitas

Uji multikolinearitas sendiri memiliki 2 acuan, yaitu berdasarkan nilai toleransi dimana nilai toleransi harus memenuhi $>0,10$ dan acuan lainnya adalah melihat nilai Variance Inflation Factor (VIF) yang muncul harus memenuhi $<10$, maka bisa dikatakan model yang akan dianalisis bebas dari multikolinearitas [2]. Hasil dari uji multikolinearitas menunjukkah bahwa baik model regresi dan diskriminan tidak terjadi multikolinearitas.

\section{- Uji Homoskedastisitas}

Uji homoskedastisitas yang bertujuan untuk mencari tahu apakah data yang digunakan pada penelitian ini bersifat homogen. Pada penelitian ini terdapat 2 metode yang berbeda untuk melihat apakah data bersifat homogen, yang pertama adalah dengan menggunakan scatter plot dan yang kedua adalah dengan melihat nilai signifikansi dari Box's M. Scatter plot digunakan untuk menguji homoskedastisitas pada analisis regresi sedangkan Box's $M$ adalah metode yang digunakan untuk menguji homogenitas pada analisis diskriminan. Hasil uji homoskedastisitas pada penelitian ini menunjukkah data yang dipakai bersifat homogen.

\section{Analisis Diskriminan Berganda}

Pada penelitian ini akan dilakukan 7 proses analisis diskriminan untuk mencari tahu pengelompokkan responden dari 7 kategori produk yang berbeda. Adapaun hasil dari analisis diskriminan berganda sebagai berikut:

\section{- Passenger Car Motor Oils}

Pada kategori ini Pertamina Lubricants dicirikan sebagai merek yang unggul pada atribut kemudahan diperoleh, harga dan juga kepopuleran merek. Tidak ada merek lain yang 
menjadi pesaing terdekat Pertamina.



Gambar 4 Perceptual map (passenger car motor oils)

\section{- Heavy Duty Diesel Oils}

Pada kategori ini Pertamina Lubricants dicirikan sebagai merek yang unggul pada atribut kemudahan diperoleh dan juga harga Artinya Pertamina merupakan produk dengan harga paling murah dan juga paling mudah didapatkan. Untuk Petronas sendiri dicirikan dengan atribut performa dan usia pakai, artinya Petronas dipersepsikan sebagai pelumas dengan performa terbaik dan usia pakai paling irit. Sedangkan Castrol dicirikan dengan atribut kepopuleran dan kemasan, artinya Castrol dipersepsikan sebagai produk yang paling popular dan juga memiliki kemasan yang baik.

- $\quad$ Powershift \& Hydraulic Oils

Pada kategori ini Pertamina Lubricants dicirikan sebagai merk yang unggul hanya pada atribut harga. Untuk merek Shell sendiri atribut yang paling melekat adalah performa dan usia pakai. Untuk ketiga variabel atribut yaitu kemudahan diperoleh kepopuleran dan kemasan memang tidak dicirikan kepada merek manapun, namun bila kita lihat pada peta tersebut Shell dan Pertamina memiliki jarak yang cukup dekat dengan ketiga atribut tersebut.

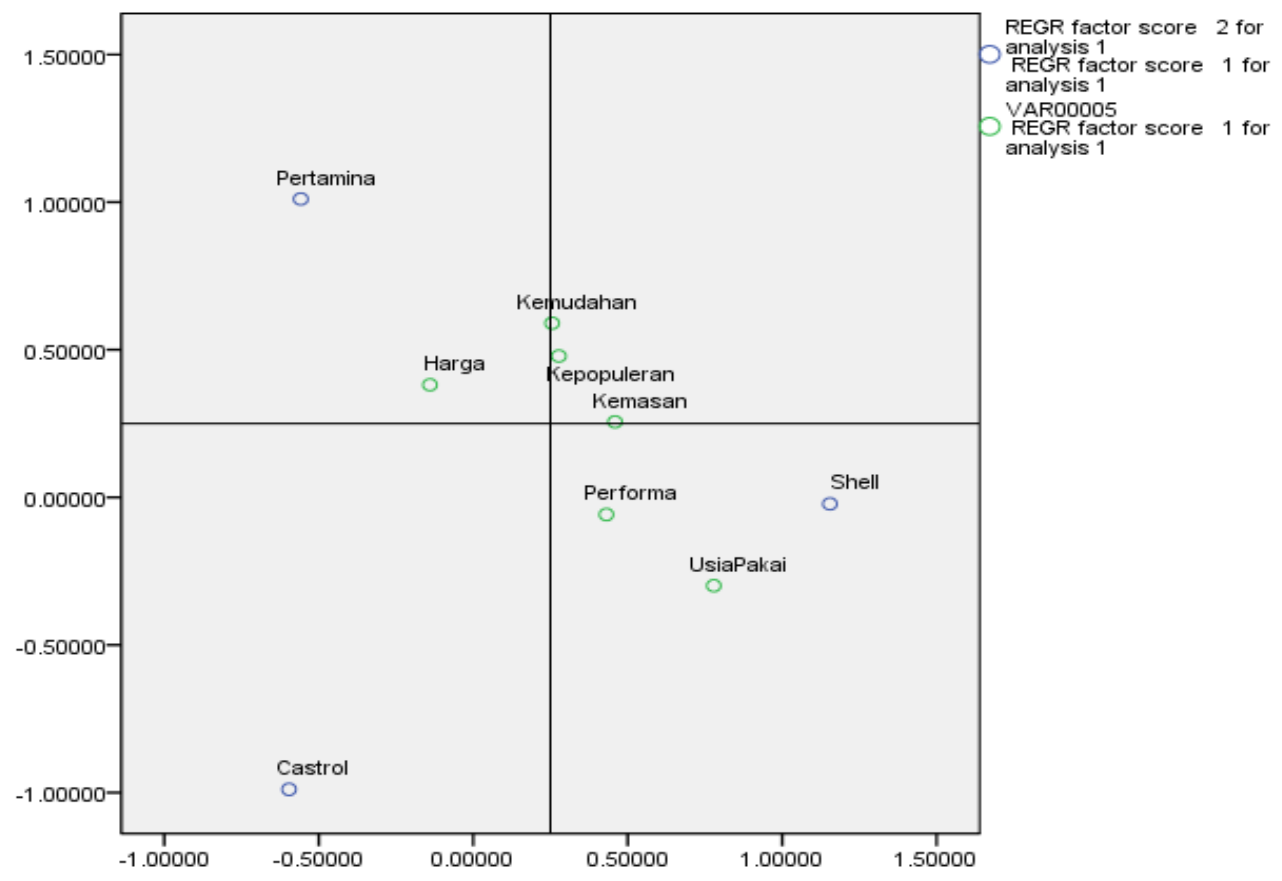

Gambar 5 Perceptual map (powershift \& hydraulic oils) 


\section{- $\quad$ Automatic \& Manual Transmission Oils}

Berdasarkan perceptual map diatas jarak antar Pertamina dengan kemudahan diperoleh merupakan yang terdekat, hal ini menunjukkan bahwa Pertamina dicirikan dengan atribut kemudahan diperoleh. Sedangkan jarak Shell dengan atribut usia pakai, performa dan kemasan merupakan yang terdekat, sehingga Shell dicirikan sebagai merek dengan atribut performa, usia pakai, dan kemasan terbaik. Berdasarkan jarak pada peta dan juga fugnsi diksriminan yang ada merek Castrol dan Pertamina memang lebih dekat dengan atribut harga.

\section{- Industrial Gears, Hydraulic \& Turbune Oils}

Pertamina sendiri pada kategori ini memiliki jarak terdekat pada atribut harga, kemudahan diperoleh dan kepopuleran merek. Untuk Shell sendiri memiliki jarak terdekat dengan atribut performa, kemasan dan usia pakai. Sehingga Shell dicirikan sebagai produk yang unggul pada ketiga atribut ini.
Untuk merek Pertamina memiliki jarak terdekat dengan atribut harga, hal ini menunjukkan bahwa Pertamina dicirikan sebagai produk yang unggul pada atribut harga. Untuk merek Shell memiliki jarak paling dekat dengan atribut performa, kepopuleran merek dan usia pakai, hal ini menunjukkan bahwa merek Shell dicirikan sebagai produk yang unggul pada ketiga atribut ini. . Untuk merek Certop sendiri memiliki jarak terdekat dengan atribut kemasan, artinya Certop dicirikan sebagai merek yang unggul pada atribut kemasan.

\section{- $\quad$ Small Engine Oils}

Pertamina memiliki jarak terdekat dengan atribut kemudahan diperoleh, harga dan kepopuleran merek. Sedangkan merek Shell memiliki jarak terdekat dengan atribut performa, usia pakai dan juga kemasan. Hal ini menunjukkan bahwa Shell dicirikan sebagai produk yang unggul pada ketiga atribut tersebut.

\section{- $\quad$ Refrigerating Oils, Heat Trasnfer Oils \& Greases}

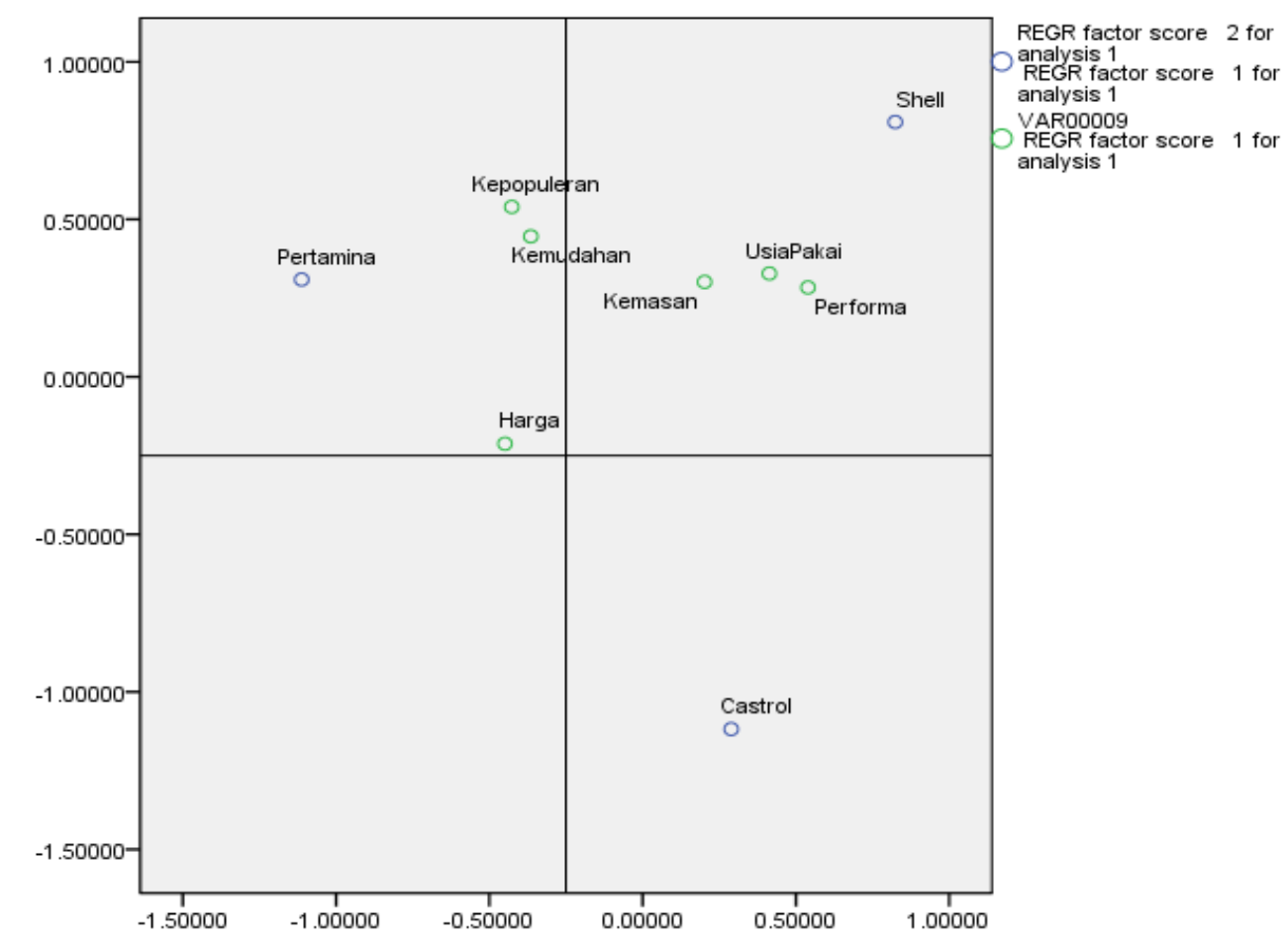

Gambar 6 Perceptual map (passenger car motor oils)

\section{E. Analisis Regresi}

Metode regresi linear berganda adalah langkah pertama yang akan dilakukan untuk mengetahui pengaruh variabel performa, usia pakai, kemudahan diperoleh, harga, kemasan dan kepopuleran merek terhadap manfaat yang dirasa.

Tabel 1

Hasil analisis regresi berganda

\begin{tabular}{lccc}
\hline \hline \multicolumn{1}{c}{ Model } & Koefisien & $\boldsymbol{\beta}$ & Signifikansi \\
\hline Konstanta & 0,007 & & 0,959 \\
Performa $\left(\mathrm{X}_{1}\right)$ & 0,109 & 0,117 & 0,009 \\
Usia pakai $\left(\mathrm{X}_{2}\right)$ & 0,173 & 0,220 & 0,000 \\
Kemudahan diperoleh & 0,152 & 0,167 & 0,001 \\
$\left(\mathrm{X}_{3}\right)$ & 0,219 & 0,243 & 0,000 \\
Harga $\left(\mathrm{X}_{4}\right)$ & 0,131 & 0,155 & 0,000 \\
Kemasan $\left(\mathrm{X}_{5}\right)$ & 0,215 & 0,266 & 0,000 \\
Kepopuleran $\left(\mathrm{X}_{6}\right)$ & & & \\
\hline \hline
\end{tabular}

Berdasarkan hasil analisis regresi berganda didapatkan bahwa seluruh koefisien regresi bernilai positif, sehingga seluruh variabel independen memiliki pengaruh positif terhadap variabel dependen. Variabel kepopuleran merek dan harga merupakan variabel yang memiliki pengaruh paling besar dengan nilai beta 0,266 dan 0,243 . Pada output regresi linear berganda diperoleh nilai $\mathrm{R}$ sebesar 0,869 . Nilai $\mathrm{R}$ sendiri memiliki range dari 0 sampai dengan 1 . Semakin mendekati nilai 1 artinya hubungan yang terjadi semakin kuat dan begitu juga sebaliknya [9].

Tabel 2

Hasil analisis regresi sederhana

\begin{tabular}{lccc}
\hline \hline \multicolumn{1}{c}{ Model } & Koefisien & $\boldsymbol{\beta}$ & Signifikansi \\
\hline Konstanta & 1,545 & & 0,000 \\
$\begin{array}{l}\text { Manfaat yang dirasa } \\
\left(\mathrm{Y}_{1}\right)\end{array}$ & 0,606 & 0,560 & 0,000 \\
\hline \hline
\end{tabular}


Berdasarkan hasil dari analisis regresi linear sederhana, diperoleh nilai konstanta untuk persamaan regresi, dan juga koefisien variabel manfaat yang dirasa. Koefisien variabel manfaat yang dirasa bernilai positif sehingga variabel independen memiliki pengaruh positif terhadap dependen. Pada analisis regresi sederhana ini diperoleh nilai R sebesar 0,560.

\section{F. Uji Hipotesis}

- $\mathrm{H}_{1}=$ Performa oli berpengaruh positif signifikan terhadap mafaat yang dirasa. (diterima)

- $\mathrm{H}_{2}=$ Umur pakai oli berpengaruh positif signifikan terhadap manfaat yang dirasa. (diterima)

- $\mathrm{H}_{3}=$ Kemudahan diperoleh berpengaruh positif signifikan terhadap manfaat yang dirasa. (diterima)

- $\mathrm{H}_{4}=$ Harga berpengaruh positif signifikan terhadap manfaat yang dirasa. (diterima)

- $\mathrm{H}_{5}=$ Kemasan berpengaruh positif signifikan terhadap manfaat yang dirasa. (diterima)

- $\mathrm{H}_{6}=$ Kepopuleran merek berpengaruh positif signifikan terhadap manfaat yang dirasa. (diterima)

- $\mathrm{H}_{7}=$ Manfaat yang dirasa berpengaruh positif signifikan terhadap kepuasan pelanggan. (diterima)

\section{G. Implikasi Manajerial}

Berdasarkan hasil analisis diskriminan yang dilakukan, diperoleh bahwa konsumen pelumas memilih merek oli berdasarkan atribut yang menonjol pada merek tersebut. Pembahasan mengenai hasil dari penelitian ini akan dibahas lebih rinci sesuai dengan kategori produk sebagai berikut:

Tabel 3

Implikasi manajerial

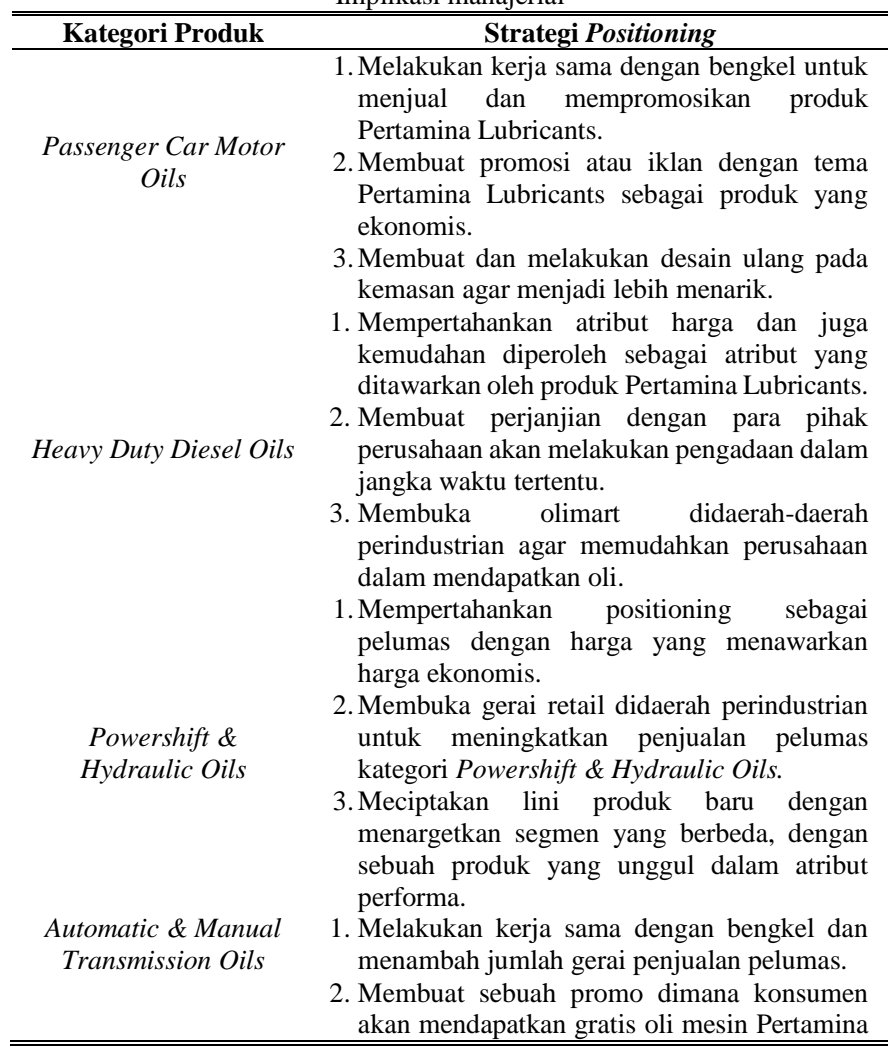

apabila melakukan penggantian oli transmisi merek Pertamina

\section{Industrial Gears, Hydraulic \& Turbine Oils}

Refrigerating Oils, Heat Transfer Oils \& Greases Small Engine Oils

Secara Keseluruhan kemudahan diperoleh sebagai atribut yang ditawarkan oleh produk Pertamina Lubricants.

2. Melakukan kerja sama dengan perusahaan dalam pengadaan pelumas dan juga edukasi mengenai pelumas mana yang lebih cocok pada mesin-mesin perusahaan.

3. Membuka penjualan pelumas didaerah-daerah perindustrian.

1. Mempertahankan atribut harga dan juga kemudahan diperoleh sebagai atribut yang ditawarkan oleh produk Pertamina Lubricants.

1. Membuat positioning statement produk Pertamina Lubricants sebagai produk yang menawarkan atribut mudah diperoleh, harga yang terjangkau dan juga produk yang populer.

2. Mendapatkan pengakuan dan melakukan kerja sama dengan pihak Honda dan Yamaha sebagai produsen motor terbesar di Indonesia.

1. Memperioritaskan untuk memenangkan persaingan pada atribut passenger car motor oils, heavy duty diesel oils dan juga small engine oils.
1. Mempertahankan atribut harga dan juga

\section{SIMPULAN DAN SARAN}

\section{A. Simpulan}

Para konsumen Pertamina Lubricants telah mencirikan produk Pertamina Lubricants sebagai pelumas yang unggul pada atribut kemudahan diperoleh, harga dan juga kepopuleran merek. Dengan mengetahui ketiga atribut yang menonjol tersebut, Pertamina kedepannya dapat memperhatikan ketiga aspek tersebut dan dapat menjadikan ketiga aspek tersebut sebagai strategi positioning merek.

Kepopuleran merek, harga dan juga usia pakai dari produk Pertamina Lubricants memiliki pengaruh yang paling besar terhadap manfaat yang dirasakan konsumen. Diperoleh bahwa manfaat yang dirasakan pelanggan memiliki pengaruh positif dan signifikan terhadap tingkat kepuasan pelanggan Pertamina.

Didapatkan bahwa atribut harga dan kepopuleran merek merupakan atribut yang dicirikan sebagai produk Pertamina dan juga paling besar pengaruhnya terhadap manfaat yang dirasakan. Kedepannya Pertamina bisa menciptakan sebuah strategi atau pendekatan positioning berdasarkan kedua atribut ini.

\section{B. Saran}

Sebaiknya Pertamina Lubricants menindaklanjuti apa yang telah disampaikan agar bisa menjaga dan meningkatkan kepuasan pelanggan mereka. Tingkat kepuasan ini bisa dicapai apabila produk yang ditawarkan memberikan manfaat yang lebih kepada konsumen Pertamina Lurbicants. Kedepannya penelitian seperti ini bisa dilakukan tidak hanya untuk pelumas saja, namun hampir seluruh jenis produk. Penelitian ini dilakukan kepada 7 jenis kategori produk Pertamina, kedepannya penelitian bisa memfokuskan pada satu jenis produk, menambah jumlah atribut dan juga jumlah merek yang 
bersaing pada dapat membuat peta persaingan semakin jelas. Sehingga hasil penelitian bisa membantu pihak perusahaan dalam merumuskan strategi pemasaran.

\section{DAFTAR PUSTAKA}

[1] Anderson, J.R. \& Bower, G.H. (1979), Human Associative Memory, Lawrence Erlbaum, Hillsdale, New Jersey.

[2] Belsley, D. A., Kuh, E. \& Welsch, R. E. (1980). Regression Diagnostics \pm Identifying Influential Data and Sources of Collinearity. New York: John Wiley and Sons.

[3] Ghozali, I. (2011). Aplikasi Analisis Multivariate Dengan Program IBM SPSS 19 (edisi kelima). Semarang: Universitas Diponegoro..

[4] Hair, J. F., Black, W. C., Babin, B. J., \& Anderson, R. E. (2014). Multivariate Data Analysis (7th ed). NJ: Pearson Prentice-Hall.

[5] Hauser, J.R. \& Koppelman, F.S. (1979). Alternative perceptual mapping techniques: relative accuracy and usefulness. Journal of Marketing Research, 16(4): 495-506.

[6] Hidayat. (2012). Industri Pelumas Tumbuh Pesat. (Online). (http://www.kemenperin.go.id/artikel/7108/Industri-Pelumas-Tumbuh diakses pada 11 Februari 2016).

[7] Lee, C.W. Liao, C.S., (2009). The Effects of consumer preferences and perceptions of Chinese tea beverages on brand positioning strategies, British Food Journal, 111(1): 80-96.

[8] Malhotra, N. K. (2009). Riset Pemasaran: Pendekatan Terapan (edisi 4). Jakarta: PT INDEKS.

[9] Neolaka, A. (2014). Metode Penelitian dan Statistik. Bandung: Rosda

[10] Ridha, M. (2005). Analisis Strategi Positioning Pelumas Mesran. Program Magister Manajemen Agribisnis, Institut Pertanian Bogor.

[11] Sekaran, U. (2006). Metodologi penelitian untuk bisnis. Jakarta: Salemba Empat.

[12] Sugiyono, (2008). Metode Penelitian Kunatitatif Kualitatif dan R\&D. Bandung Alfabeta.

[13] Wibisono, D. (2003). Riset Bisnis Panduan Bagi Praktisi dan Akademisi. Jakarta: Gramedia Pustaka Utama.

[14] Zeithaml, V.A. Bitner, M.J. (2003) Service Marketing. New York. McGraw Hill Inc. 